\title{
Green Development Assessment of a Stainless-steel Industrial Park Based on Material Flow Analysis (MFA)
}

\author{
Zhijie Jia, Mengfan He, Junjie Mou, Geng Ge, Quanhui Yang, Wei Liu* \\ College of resources and environment, Chengdu University of Information Technology, 610225, China
}

\begin{abstract}
Based on the material flow analysis method, the green development index system of industrial park was constructed. By using the PSR model, 13 indexes were divided into pressure layer, state layer and response layer, the indexes were standardized, weight distribution and synthesis. The green development level of industrial park was divided into 5 grades combined with the pressure state response factors. The results show that the energy consumption per unit industrial output of a stainless-steel industrial park is 0.7116 tons of standard coal per million yuan, the water consumption per unit industrial output is 6.1466 cubic meters per million yuan, the wastewater discharge per unit industrial added value is 3.12 tons per million yuan, the reduction rate of carbon emissions per unit industrial added value is $19.53 \%$, and the green development index is 0.65 , which belongs to the third level of green development. The problems are reflected in particulate emission, resource recycling, energy efficiency, industrial structure, and park greening. In the future, the stainless-steel industrial park should focus on industrial restructuring and transformation, environmental protection infrastructure construction, new policy guidance, and ecological environment construction of the park.
\end{abstract}

\section{Introduction}

Industrial parks are the most direct manifestation of mature industrial systems and will be generally established and developed in the process of industrial structure adjustment and upgrading throughout the country. With the upsurge of industrial park construction, if not properly managed, it will be easy to cause serious resource consumption and environmental pollution problems caused by industrial park production activities, and then restrict the future development of industrial $\operatorname{park}^{[1-2]}$.

Material flow analysis is an effective method to study the industrial metabolism of specific substances in a country or region ${ }^{[3]}$. According to the principle of industrial ecology, through the inter-enterprise material, energy and information integration, the formation of inter-industry metabolism and symbiosis coupling relationship, improve the output rate and ecological level of industrial parks are improved, and the overall competitive advantage and sustainable development ability of industrial parks are enhanced ${ }^{[4-5]}$.

The core of green development of industrial park is the construction of ecological industry, and ultimately win-win of ecological environment and economy. The green development level of industrial park is to measure the impact of economic development on resource consumption and environment under the comprehensive consideration of economic development, resource utilization and ecological environment protection. Through the establishment of industrial park green development level evaluation index system, reflect the influence of industrial park on regional environmental quality and improvement potential ${ }^{[4-5]}$.

The material flow of industrial parks is analysed to understand the flow of resources and energy in industrial parks and the emission of pollutants in production activities. Based on the material flow analysis, the evaluation index system of green development of industrial parks are constructed. The index system is used to systematically evaluate the industrial parks, and the ways to save resources and energy and improve environmental quality are obtained. Finally, the transformation of industrial parks to green sustainable development is achieved.

\section{Research method}

\subsection{Material Flow Analysis of Industrial Park}

MFA of industrial park is to describe the source, confluence and path of material flow in specific industrial park within a given time span, revealing the correlation characteristics and laws between economic development of industrial park and resource input and pollution output, so as to serve the circular transformation and ecological transformation and upgrading of industrial park. The fundamental frame of MFA about the industrial park is made up of three blocks which include material input, park system and material output ${ }^{[4-5]}$. MFA indicators generally include system

Wei Liu: weling9@163.com 
scale, structure, level and the indicators of efficiency, such as resource output rate, pollution emission intensity, direct material input, direct environmental emission and material stock changes.

\subsection{Model}

The model of Pressure-State-Response (PSR) uses the logical thinking of "Pressure-State-Response" so as to reflect the interaction between human beings and the environment ${ }^{[6-7]}$. See Figure 1 for the PSR model framework of green development of industrial park.



Fig. 1. The PSR model framework of green development of industrial park.

\subsection{Assessment of green development level of industrial park}

\subsubsection{Evaluation index system for green development of industrial park}

The construction process of evaluation indexing system for green development of industrial parks includes the steps: to build the evaluation indexing system; analyze and determine the connotation of the industrial park, collect design indicators in terms of economic development, environmental governance, industrial structure, recycling, park management and ecological livability, and select indicators with high frequency. Finally, the evaluation indexing system of green development of industrial parks is determined ${ }^{[8-13]}$.

\subsubsection{Evaluation method for green development of industrial parks}

Reference value determined. Reference values are determined after considering the following principles, such as: considering the country or industry, the standard shall adopt the specified values in the standard as far as possible; consistent with or better than the target value of relevant policy research; considering the actual development of the park; taking the development planning as the target value; shortage of significant statistical, using expert consultation, qualitative description and other methods to determine.

Standardized treatment. Due to the different properties and dimensions of each index, it cannot be used for direct calculation, so it is necessary to standardize the index, which is equal to relative values can be obtained by comparing the selected reference values and index values. The processing mode is shown in Table 1:

Table 1. Reference value standardization processing method.

\begin{tabular}{|c|c|c|c|}
\hline \multicolumn{2}{|c|}{ Target classification } & $\begin{array}{l}\text { Standardized } \\
\text { results }\end{array}$ & Remarks \\
\hline \multirow[b]{3}{*}{$\begin{array}{l}\text { An index } \\
\text { which } \\
\text { reference } \\
\text { value is } \\
\text { superior } \\
\text { to the } \\
\text { index } \\
\text { value }\end{array}$} & $\begin{array}{l}\text { The larger the } \\
\text { index data, } \\
\text { the better: }\end{array}$ & $C_{i}=1-\frac{\left(S_{i}-S\right)}{\left(S_{i}-S_{\min }{ }^{1}\right)}$ & \multirow{3}{*}{$\begin{array}{l}\text { In the } \\
\text { formula, } C_{i} \text { is } \\
\text { the } \\
\text { standardized } \\
\text { processing } \\
\text { value of the } \\
\text { index, } S_{i} \text { is } \\
\text { the reference } \\
\text { value of the } \\
\text { index, } \mathrm{S} \text { is the } \\
\text { value of the } \\
\text { index, } S_{\text {max }} \text { is } \\
\text { the maximum } \\
\text { value of the } \\
\text { index, and } \\
S_{\min } \text { is the } \\
\text { maximum } \\
\text { value of the } \\
\text { current status } \\
\text { of the index. } \\
\text { Among: } \\
S_{\max }{ }^{1} \\
=S_{\max } * 1.05 \\
S_{\min }{ }^{2} \\
=S_{\min } / 1.05\end{array}$} \\
\hline & $\begin{array}{c}\text { The smaller } \\
\text { the indicator } \\
\text { data, the } \\
\text { better: }\end{array}$ & $\mathrm{C}_{\mathrm{i}}=1-\frac{\left(\mathrm{S}-\mathrm{S}_{\mathrm{i}}\right)}{\left(\mathrm{S}_{\max }{ }^{1}-\mathrm{S}_{\mathrm{i}}\right)}$ & \\
\hline & $\begin{array}{l}\text { For other } \\
\text { indicators: }\end{array}$ & $\mathrm{C}_{\mathrm{i}}=1-\frac{\left|\mathrm{S}_{\mathrm{i}}-\right|}{\left(\mathrm{S}_{\max }{ }^{1}-\mathrm{S}_{\min }{ }^{1}\right)}$ & \\
\hline \multicolumn{2}{|c|}{$\begin{array}{l}\text { An indicator whose value } \\
\text { is superior to a reference } \\
\text { value }\end{array}$} & $\begin{array}{l}\text { The standardized } \\
\text { treatment value is } 1\end{array}$ & 1 \\
\hline
\end{tabular}

Index weight is determined. In this study, analytic hierarchical process (AHP) is used to assess the indexes of green developing level of industrial parks to determine the weight. Build the hierarchical structure about the evaluation of green development level in industrial parks the target layer is green development level of industrial parks, the criterion layer is pressure, state and response factors, and the project hierarchy is various indexes. The relative importance of each layer is obtained by comparing the factors of each layer in pairs with the scale method. If $\mathrm{n}$ factors of a certain level are compared, B1, B2,... The influence of Bn on A factor A in the upper layer is identified by $\mathrm{Kij}$ as the ratio of $\mathrm{Bi}$ and $\mathrm{Bj}$ to the importance of $\mathrm{A}$, and the judgment matrix $\mathrm{K}$ is obtained through the pair comparison:

$$
K=\left[\begin{array}{cccc}
k_{11} & k_{12} & \cdots & k_{1 n} \\
k_{21} & k_{22} & \cdots & k_{2 n} \\
\vdots & \vdots & \ddots & \vdots \\
k_{m 1} & k_{m 2} & \cdots & k_{m n}
\end{array}\right]
$$

Scaling methods $1-9$ of $1,3,5,7,9$, respectively two factors are equally important, the former is slightly more important than the latter, the former is more important than the latter obviously, the former is more important than the latter strongly, the former is more important than the latter extreme, 2, 4, 6, 8 identification before the latter than in the middle of the values, the degree of the former than the latter is not important with reciprocal $\left(K_{i j}=1 / K_{i j}\right)$ said.

By calculating the eigenvalue and vector of the judgment matrix, the priority is completed. The second 
part concludes that the judgment calculates the maximum eigenvalue and eigenvector $\mathrm{X}$, and then normalizes the eigenvector $\mathrm{X}$. The vector component $\mathrm{X}$ obtained is the weight of the factor applied to the upper layer. This research is realized by MATLAB program.

Table 2. The calculation of weight ranking.

\begin{tabular}{|c|c|}
\hline Steps & Formulas \\
\hline Matrix K per row index product $\boldsymbol{T}_{\boldsymbol{i}}$ & $\boldsymbol{T}_{\boldsymbol{i}}=\prod_{j}^{n} \boldsymbol{k}_{\boldsymbol{i} \boldsymbol{j}}$ \\
\hline $\begin{array}{c}\text { The eigenvector is divided into the } \\
\text { vector } \overline{\boldsymbol{X}_{\boldsymbol{i}}}\end{array}$ & $\overline{\boldsymbol{X}_{\boldsymbol{i}}}=\sqrt[n]{\boldsymbol{T}_{\boldsymbol{i}}}$ \\
\hline $\begin{array}{c}\text { The normalization is going to give me } \\
\text { the weight } \boldsymbol{X}_{\boldsymbol{i}}\end{array}$ & $X_{i}=\frac{\overline{\boldsymbol{X}_{\boldsymbol{i}}}}{\sum_{j=1}^{n} \overline{\boldsymbol{X}_{\boldsymbol{i}}}}$ \\
\hline The largest eigenvalue $\lambda$ & $\lambda=\frac{1}{n} \sum_{i=1}^{n} \frac{(K X)_{i}}{X_{i}}$ \\
\hline
\end{tabular}

In order to check the consistency of matrix, consistency index CI value and average random consistency index RI value are introduced, as shown in the following table, $\mathrm{CI}=(\lambda-\mathrm{n}) /(\mathrm{n}-1)$, and CI is compared with $\mathrm{RI}$, denoted as $\mathrm{CR}, \mathrm{CR}=\mathrm{CI} / \mathrm{RI}$. When $\mathrm{CR} \leq 0.1$, the judgment matrix has acceptable consistency; otherwise, the judgment matrix needs to be adjusted until the requirements are met.

Table 3. RI value of random consistency index.

\begin{tabular}{|c|c|c|c|c|c|c|c|c|c|}
\hline $\mathrm{n}$ & 1 & 2 & 3 & 4 & 5 & 6 & 7 & 8 & 9 \\
\hline $\mathrm{RI}$ & 0 & 0 & 0.58 & 0.90 & 1.12 & 1.24 & 1.32 & 1.41 & 1.45 \\
\hline
\end{tabular}

Index value synthesis method. The index synthesis method is shown in Table 4.

Table 4. Index synthesis method.

\begin{tabular}{|c|c|l|}
\hline Steps & Formulas & \multicolumn{1}{c|}{ Remarks } \\
\hline $\begin{array}{c}\text { Primary } \\
\text { index value }\end{array}$ & $A_{\boldsymbol{i}}=\sum_{\boldsymbol{i}=\mathbf{1}}^{n} \boldsymbol{W}_{\boldsymbol{i}} \boldsymbol{C}_{\boldsymbol{i}}$ & $\begin{array}{l}\text { In the formula: } \boldsymbol{A}_{\boldsymbol{i}} \text { is the first- } \\
\text { level index value, } \boldsymbol{W}_{\boldsymbol{i}} \text { is the } \\
\text { weight value corresponding to } \\
\text { the second-level index, } \boldsymbol{C}_{\boldsymbol{i}} \text { is the } \\
\text { standard value of the index, } \mathrm{n} \\
\text { is the number of subordinate } \\
\text { indicators. }\end{array}$ \\
\hline $\begin{array}{c}\text { Composite } \\
\text { development } \\
\text { index }\end{array}$ & $\boldsymbol{Z}=\sum_{\boldsymbol{i}=\mathbf{1}}^{\boldsymbol{m}} \boldsymbol{X}_{\boldsymbol{i}} \boldsymbol{A}_{\boldsymbol{i}}$ & $\begin{array}{l}\text { In the formula: } \mathrm{Z} \text { is the first- } \\
\text { level index value, } \boldsymbol{X}_{\boldsymbol{i}} \text { is the } \\
\text { weight value corresponding to } \\
\text { the first-level index, } \boldsymbol{A}_{\boldsymbol{i}} \text { is the } \\
\text { first-level index value, } \mathrm{m} \text { is the } \\
\text { number of items of the first- } \\
\text { level index. }\end{array}$ \\
\hline
\end{tabular}

The grade of green development level of industrial parks is divided. The green development level of industrial parks is affected by pressure, state and response factors. Stress index represents the effect of human economic and social activities on the environment, mainly describing the impact and stress brought by human activities on the environment. It can reflect the intensity of resource utilization and its changing trend in a certain period from the aspects of energy, transportation, construction and industry. The status index represents the environmental status and environmental changes at a specific time stage. It reflects the changes of environmental factors, mainly considering the biological, physical and chemical characteristics and ecological functions in the environment or ecosystem, namely land, air, suitability and satisfaction. Response index refers to that when human activities change the natural and ecological environment and bring about adverse impacts on regional environmental quality, the society will respond through environmental, economic and other policies and changes in consciousness and behavior to mitigate or eliminate the possible adverse impacts, such as a legal system, economic means, technological change and international obligations. The green development level of the industrial park is divided into 5 levels according to the response factors of pressuring state.

Table 5. Evaluation grade of green development level of industrial parks.

\begin{tabular}{|c|c|c|}
\hline Grades & Scores & Fundamental states \\
\hline \multirow{3}{*}{$\begin{array}{l}\text { First } \\
\text { stage }\end{array}$} & \multirow{3}{*}{$0.9 \sim 1$} & $\begin{array}{l}\text { Pressure: Low carbon emission intensity, lo } \\
\text { emission coefficient, low energy consumptic } \\
\text { intensity, low energy flow density, very goc } \\
\text { development of the park }\end{array}$ \\
\hline & & $\begin{array}{l}\text { Status: The air environment quality is very } \\
\text { good, the comprehensive utilization degree of } \\
\text { pollutants is high, and the public is satisfied } \\
\text { with the environment }\end{array}$ \\
\hline & & $\begin{array}{l}\text { Response: The distribution of the three } \\
\text { industries is very reasonable, with high } \\
\text { proportion of clean energy, high investment in } \\
\text { environmental protection, good energy-saving } \\
\text { technology and strong awareness of } \\
\text { environmental protection }\end{array}$ \\
\hline \multirow{3}{*}{$\begin{array}{l}\text { Second } \\
\text { stage }\end{array}$} & \multirow{3}{*}{$0.8 \sim 0.9$} & $\begin{array}{l}\text { Pressure: Low carbon emission intensity, low } \\
\text { emission coefficient, low energy consumption } \\
\text { intensity, low energy flow density, and good } \\
\text { development of the park }\end{array}$ \\
\hline & & $\begin{array}{l}\text { Status: The air environment quality is good, the } \\
\text { comprehensive utilization degree of pollutants } \\
\text { is high, and the public is satisfied with the } \\
\text { environment }\end{array}$ \\
\hline & & $\begin{array}{l}\text { Response: Rational distribution of the three } \\
\text { industries, relatively high proportion of clean } \\
\text { energy, high investment in environmental } \\
\text { protection, better energy-saving technology, } \\
\text { strong awareness of environmental protection }\end{array}$ \\
\hline \multirow{3}{*}{$\begin{array}{l}\text { Third } \\
\text { stage }\end{array}$} & \multirow{3}{*}{$0.6 \sim 0.8$} & $\begin{array}{l}\text { Pressure: moderate carbon emission intensity, } \\
\text { moderate emission coefficient, moderate energy } \\
\text { consumption intensity, moderate energy flow } \\
\text { density, general development of the park }\end{array}$ \\
\hline & & $\begin{array}{l}\text { Status: Good air quality, } \\
\text { comprehensive utilization of } \\
\begin{array}{l}\text { pollutants, } \\
\text { moderate public satisfaction with the } \\
\text { environment }\end{array}\end{array}$ \\
\hline & & $\begin{array}{l}\text { Response: The distribution of the three } \\
\text { industries is reasonable, the proportion of clean } \\
\text { energy is moderate, the investment in } \\
\text { environmental protection is moderate, the } \\
\text { technology of energy saving is general, and the } \\
\text { awareness of environmental protection of } \\
\text { enterprises and citizens is general }\end{array}$ \\
\hline \multirow{2}{*}{$\begin{array}{l}\text { Fourth } \\
\text { stage }\end{array}$} & \multirow[t]{2}{*}{$0.4 \sim 0.6$} & $\begin{array}{l}\text { Pressure: high carbon emission intensity, high } \\
\text { emission coefficient, high energy consumption } \\
\text { intensity, high energy flow density, and poor } \\
\text { development of the park }\end{array}$ \\
\hline & & $\begin{array}{l}\text { Status: Poor air quality, low } \\
\text { comprehensive utilization of pollutants, low } \\
\text { public satisfaction with the environment }\end{array}$ \\
\hline
\end{tabular}




\begin{tabular}{|l|l|l|}
\hline & $\begin{array}{l}\text { Response: Unreasonable distribution of } \\
\text { the three industries, low proportion of } \\
\text { clean energy, low investment in } \\
\text { environmental protection, backward } \\
\text { energy-saving technology, low awareness } \\
\text { of enterprise environmental protection }\end{array}$ \\
\hline Fifth & $\begin{array}{l}\text { Pressure: The carbon emission intensity is } \\
\text { very high, the emission coefficient is very } \\
\text { high, the energy consumption intensity is } \\
\text { very high, the energy flow density is very } \\
\text { high, and the development of the park is } \\
\text { very poor } \\
\text { Stage }\end{array}$ & $\begin{array}{l}\text { Status: The air environment quality is } \\
\text { very poor, the comprehensive utilization } \\
\text { degree of pollutants is very low, and the } \\
\text { public's satisfaction degree to the } \\
\text { environment is very low }\end{array}$ \\
\hline
\end{tabular}

\section{Results and discussion}

\subsection{Research data collection and processing}

Based on the data of a stainless-steel industrial park, this research summarized 37 key enterprises and several other enterprises, with a total annual output value of $13,974.225$ million yuan, they are mainly in the stainless-steel, steel, cement, and forging industries. The index data used basically comes from official authoritative data, including the second national pollution source survey, environmental quality bulletin, and water resource bulletin. Most of the evaluation index data can be obtained directly, and some data need to be processed. The preliminary data processing results are shown in Figure 2, the total amount of energy equivalent to standard coal is 994,440 tons, the total amount of water taken is $8,589,460$ cubic meters, the total amount of pollutants discharged is 199,220 tons, and the total input material is $18,1733.39$ tons.

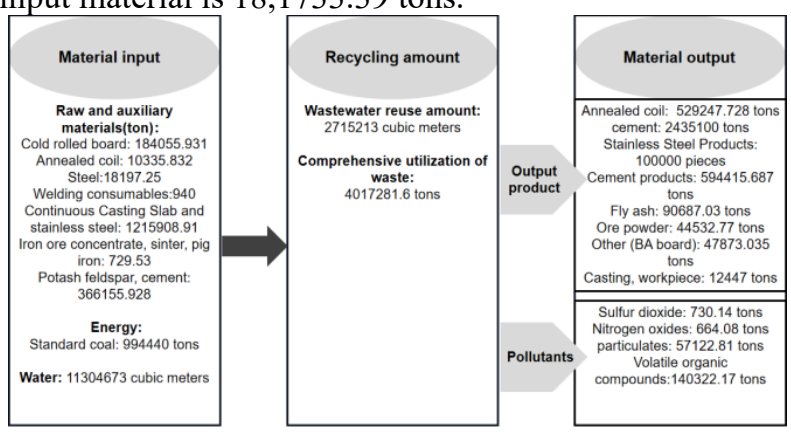

Fig. 2. Panorama of MFA about the industrial park.

\subsection{Results of MFA of the industrial park}

The evaluation indicators of MFA about the industrial park select resource output rate, pollutant emission intensity, and material input.

Table 7. The current value and standardization of the green development level indicators of the industrial park.

\begin{tabular}{|c|c|c|c|c|c|c|c|}
\hline $\begin{array}{l}\text { Target } \\
\text { layer }\end{array}$ & $\begin{array}{l}\text { First level } \\
\text { indicator }\end{array}$ & $\begin{array}{c}\text { Serial } \\
\text { number }\end{array}$ & Secondary indicators & $\begin{array}{c}\text { Current } \\
\text { value }\end{array}$ & unit & Reference & $\begin{array}{c}\text { standard } \\
\text { ization }\end{array}$ \\
\hline $\begin{array}{l}\text { Green } \\
\text { develop } \\
\text { ment }\end{array}$ & $\begin{array}{l}\text { Stress } \\
\text { indicator }\end{array}$ & 1 & $\begin{array}{l}\text { Energy consumption per unit of } \\
\text { industrial output value }\end{array}$ & 0.7116 & $\begin{array}{l}\text { Tons of standard } \\
\text { coal/ten thousand yuan }\end{array}$ & $\begin{array}{l}\leq 0.9 \text { Tons of } \\
\text { standard coal/ten } \\
\text { thousand yuan }\end{array}$ & 1 \\
\hline
\end{tabular}

Table 6. Evaluation Index of MFA of the Industrial park.

\begin{tabular}{|c|c|c|c|}
\hline $\begin{array}{c}\text { Indicator } \\
\text { name }\end{array}$ & The formula & $\begin{array}{c}\text { The } \\
\text { formula }\end{array}$ & unit \\
\hline $\begin{array}{l}\text { Substance } \\
\text { input }\end{array}$ & $\begin{array}{l}\text { Direct material } \\
\text { input add } \\
\text { indirect } \\
\text { material input }\end{array}$ & 1817323.39 & ton \\
\hline $\begin{array}{l}\text { resource } \\
\text { output rate }\end{array}$ & $\begin{array}{c}\text { Annual } \\
\text { industrial } \\
\text { output value } \\
\text { divided by } \\
\text { substance input } \\
\end{array}$ & 0.7689 & $\begin{array}{c}\text { Ten } \\
\text { thousand } \\
\text { yuan/ton }\end{array}$ \\
\hline $\begin{array}{l}\text { Energy } \\
\text { consumption } \\
\text { intensity per } \\
\text { unit industrial } \\
\text { output value }\end{array}$ & $\begin{array}{c}\text { Total energy } \\
\text { consumption } \\
\text { divided by } \\
\text { annual } \\
\text { industrial } \\
\text { output value } \\
\end{array}$ & 0.7116 & $\begin{array}{c}\text { tec/ten } \\
\text { thousand } \\
\text { yuan }\end{array}$ \\
\hline $\begin{array}{c}\text { Water } \\
\text { consumption } \\
\text { intensity per } \\
\text { unit industrial } \\
\text { output value }\end{array}$ & $\begin{array}{c}\text { Industrial water } \\
\text { divided by the } \\
\text { annual output } \\
\text { value of } \\
\text { industry } \\
\end{array}$ & 6.1466 & $\begin{array}{c}\text { Cubic } \\
\text { meter/ten } \\
\text { thousand } \\
\text { yuan }\end{array}$ \\
\hline $\begin{array}{l}\text { Pollutant } \\
\text { emission } \\
\text { intensity per } \\
\text { unit industrial } \\
\text { output value }\end{array}$ & $\begin{array}{c}\text { Pollutant } \\
\text { emissions } \\
\text { divided by } \\
\text { annual } \\
\text { industrial } \\
\text { output value }\end{array}$ & 0.1426 & $\begin{array}{c}\text { Tons/ten } \\
\text { thousand } \\
\text { yuan }\end{array}$ \\
\hline
\end{tabular}

Due to the analysis of the evaluation index results of the MFA of the industrial park, the enterprises in the industrial park have overcapacity, insufficient innovation and development capabilities, unsustainable economic development, and new difficulties in business operations; The industrial park is small in scale, the products are relatively single and the added value is low, the advantages of industrial development are not obvious, and the development experience is insufficient; The ferrous metal smelting and rolling processing industry in the industrial park, as well as the cement industry's resource consumption and pollution reduction, are under pressure; New environmental problems such as heavy metals, persistent organic pollutants, and particulate matter have become increasingly prominent, and pollution reduction and environmental pressure have increased.

\subsection{Results of the evaluation of the green development level of the industrial park}

Refer to Table 7 for the reference value, current value and corresponding standardized value of the green development level evaluation index of the industrial park. 


\begin{tabular}{|c|c|c|c|c|c|c|c|}
\hline \multirow{15}{*}{$\begin{array}{l}\text { level of } \\
\text { industri } \\
\text { al park }\end{array}$} & & 2 & $\begin{array}{l}\text { Water consumption per unit } \\
\text { industrial output value }\end{array}$ & 6.1466 & $\begin{array}{l}\text { Cubic meter/ten } \\
\text { thousand yuan }\end{array}$ & $\begin{array}{c}\leq 9 \text { Cubic meter/ten } \\
\text { thousand yuan }\end{array}$ & 1 \\
\hline & & 3 & $\begin{array}{c}\text { Wastewater discharge per unit of } \\
\text { industrial added value }\end{array}$ & 3.12 & Tons/ten thousand yuan & $\begin{array}{l}\leq 8 \text { Tons } / \text { ten } \\
\text { thousand yuan }\end{array}$ & 1 \\
\hline & & 4 & $\begin{array}{l}\text { Reduction rate of carbon } \\
\text { emissions per unit of industrial } \\
\text { added value }\end{array}$ & 19.53 & $\%$ & $\geq 22 \%$ & 0.274 \\
\hline & \multirow{6}{*}{$\begin{array}{l}\text { Status } \\
\text { indicator }\end{array}$} & 5 & Air quality good rate & 67.39 & $\%$ & $\begin{array}{l}\text { Meet the functional } \\
\text { area standard }\end{array}$ & 1 \\
\hline & & 6 & $\begin{array}{l}\text { Comprehensive utilization rate } \\
\text { of industrial solid waste }\end{array}$ & 99.39 & $\%$ & $\geq 85 \%$ & 1 \\
\hline & & 7 & Industrial water reuse rate & 52.83 & $\%$ & $\geq 75 \%$ & 0.176 \\
\hline & & 8 & $\begin{array}{c}\text { Centralized treatment rate of } \\
\text { domestic sewage }\end{array}$ & 90 & $\%$ & $\geq 85 \%$ & 1 \\
\hline & & 9 & Green coverage & 23.8 & $\%$ & $\geq 40 \%$ & 0.065 \\
\hline & & 10 & $\begin{array}{c}\text { Public satisfaction with the } \\
\text { environment }\end{array}$ & $80 \%$ & $\%$ & $\geq 90 \%$ & 0.571 \\
\hline & \multirow{6}{*}{$\begin{array}{l}\text { Response } \\
\text { indicator }\end{array}$} & 11 & $\begin{array}{c}\text { The proportion of high-tech } \\
\text { industries in the industrial output } \\
\text { value of the whole district }\end{array}$ & 59.56 & $\%$ & $50 \% \sim 80 \%$ & 1 \\
\hline & & 12 & $\begin{array}{l}\text { Percentage of the added value of } \\
\text { green industry in the industrial } \\
\text { added value of the park }\end{array}$ & 6.27 & $\%$ & $\geq 15 \%$ & 0.033 \\
\hline & & 13 & Clean energy usage rate & 20.37 & $\%$ & $\geq 50 \%$ & 0.032 \\
\hline & & 14 & $\begin{array}{l}\text { Percentage of green buildings in } \\
\text { new industrial buildings }\end{array}$ & 0 & $\%$ & $\geq 50 \%$ & 0 \\
\hline & & 15 & $\begin{array}{l}\text { Environmental report prepared } \\
\text { by the park }\end{array}$ & 1 & Period/year & 1Period/year & 1 \\
\hline & & 16 & $\begin{array}{l}\text { Implementation rate of cleaner } \\
\text { production audit of enterprises } \\
\text { above designated size }\end{array}$ & 100 & $\%$ & $100 \%$ & 1 \\
\hline
\end{tabular}

The calculation of the weights of the evaluation indicators for the green development level of the industrial park is as follows, where A represents the target level, that is, the green development level of the industrial park.

Table 8. First-level index judgment matrix.

\begin{tabular}{|c|c|c|c|}
\hline $\mathrm{A}$ & pressure & status & response \\
\hline pressure & 1 & 3 & $1 / 2$ \\
\hline status & $1 / 3$ & 1 & $1 / 5$ \\
\hline response & 2 & 5 & 1 \\
\hline
\end{tabular}

Note: The consistency ratio of the judgment matrix is 0.0032 .

The consistency ratio of pressure, state and response index judgment matrix is $0,0.0562$ and 0.0241 , respectively.

See Table 9 for the first-level indicator values of the green development index of the industrial park, the green development index of the industrial park is 0.65 , and the green development index belongs to the third level.

Table 9. The first-level indicator value of the green development level of the industrial park.

\begin{tabular}{|c|c|c|c|}
\hline & $\begin{array}{c}\text { Stress } \\
\text { indicator }\end{array}$ & $\begin{array}{c}\text { Status } \\
\text { indicator }\end{array}$ & $\begin{array}{c}\text { Response } \\
\text { indicator }\end{array}$ \\
\hline Numerical & 0.72775 & 0.62998 & 0.61372 \\
\hline
\end{tabular}

Green Industrial park development level at the middle level, there is some discrepancy from the target green industrial park, compared with the PSR model, the main problems restricting the green development of the industrial park are analysed as follows:

The regional ambient air quality exceeds the standard, which is specifically manifested in the excessive inhalable particulate matter. The main reason is that the industrial park is located on the edge of the basin and belongs to the mountainous area of the basin. The landform is mainly mountainous, which is not conducive to the diffusion of pollutants; The second is that the industrial park has two large steel companies and two cement companies, and the total amount of pollutant emissions is large. At the same time, the informative construction of the industrial park is poor, the ecological industrial information platform lacks much information, and the construction of the platform is not perfect. The public cannot have a deep understanding of the process of Ecological degree, greening, and sustainable development of the industrial park. In summary, residents around the industrial park are less satisfied with the environmental construction of the industrial park;

The industrial park is dominated by steel, cement, and forging enterprises. There are very few green industries, resulting in a very low proportion of green industry added value. At the same time, the construction of environmental protection infrastructure in the industrial park is lagging behind and no industrial solid waste disposal site has been built, and solid waste recycling, treatment and disposal are in a blank state; The sewage pipe network is not sound and the sewage collection rate is low, which makes little contribution to sewage treatment. The concept of circular economy in industrial park enterprises is poor, and only large-scale enterprises have carried out technological transformation. Most small and medium-sized enterprises value shortterm economic benefits, with low resource recycling rate, low use rate of clean energy, and low investment in environmental protection facilities;

Compared with the construction area, the green area of the industrial park is relatively small, the green coverage rate is low, and there are no green buildings in 
the newly-built industrial buildings, and the ecological environment of the industrial park is poor.

\section{Conclusion}

Based on the MFA method, a stainless-steel industrial park output of a stainless-steel industrial park in 2017 were studied. At the same time, combined with the evaluation of the green development level of the industrial park, 17 indexes were established to evaluate the industrial park, and 8 indexes were not up to the standard: reduction of carbon emissions per unit of industrial value added, reuse of industrial water, green coverage, public satisfaction with the environment, the proportion of green industry added value to the industrial added value of the park, the utilization rate of clean energy, the proportion of green buildings in newly built industrial buildings, the perfection of ecological industry information platform.

The energy consumption of the industrial park enterprises in coal, oil and other oil and other resourcebased materials, high in proportion to the proportion of iron and steel, cement, casting and other resource-based industries, the industrial structure of the industrial park needs to be optimized, the following recommendations are made:

Industrial category adjustment and distribution: the transformation and upgrading of traditional heavy industries, the development of high-tech green industries and modern service industries, and the active introduction of new materials, new energy, advanced equipment and other "high-tech light and clean" emerging industries. Metallurgical building materials industry upgrade transformation, orderly withdrawal from cement, steel primary, low-end ceramics and other traditional industries;

The industrial park should strengthen the construction of environmental protection infrastructure, especially sewage treatment and solid waste comprehensive utilization and disposal facilities. Environmental access to construction projects also needs to be adjusted accordingly: strict control of high pollution, high energy consumption, high water consumption projects into the park; require existing steel, cement, and other high energy consumption enterprises to implement ultra-low emission transformation and strictly limit production capacity; to improve and optimize the industrial structure of the three types of parks, improve new materials, new energy sources, green building materials, the proportion of modern logistics and other industries; enterprises that do not meet the current national industrial policy and their government environmental access requirements are prohibited from entering the park; new construction, reconstruction and expansion projects must adopt advanced production technology, equipment and pollution control technology, clean production level is not lower than the second level; the existing and new projects in the park strictly implement national and local pollutant emission standards;
The industrial park should adhere to the combination of fast-growing tree species and slow-growing tree species, evergreen trees and deciduous trees, scientific allocation of public green space and greening tree species. To actively build green corridors of industrial parks, with emphasis on strengthening the greening of ecological corridors such as main roads, secondary trunk roads and branch roads;

Through policy guidance, we can arouse the enthusiasm of enterprises in the application of energy saving and emission reduction technology, promote the development of energy saving and environmental protection industry, and promote the protective development of enterprises to the environment. Enterprises are encouraged to carry out scientific technical reform, improve the repeated use of industrial water, increase the recycling of industrial solid waste, and establish the circular economy of the park.

\section{Acknowledgement}

This research was supported by the undergraduate innovation and entrepreneurship training program: study on the green development of typical industrial park in Sichuan Province based on MFA (No. S202010621120).

\section{References}

1. R.N. Zhao, Z. Ma, Q. Qiao, D.H. Hu, Y. Zhang, M.H. Xie, J. Guo. J. RES. 33 (02). 511 (2020)

2. Y.X. Xu, C.H. Cui, K. Chen, Y.D. Tang. J. EP. 47 (21). 69 (2019)

3. H. Cheng, X.C. Peng, Z.L. Chen, J.H. Dong. J. ESM. 36 (10). 142 (2011)

4. P.H. Gu, Z.C. Liu. J. EG. 37 (04). 142 (2017)

5. C.X. Zhang, Y. Wang. J. SM. 06. 51 (2019)

6. H. Zhao, X. Yan, F.Q. Wang, P.P. Kang. J. WRP. 36 (04). 21 (2020)

7. S. Das, B. Pradhan, P.K. Shit, A.M. Alamri. J. S. 12 (15). (2020)

8. Y.L. Xing, B. Feng. J. EPS. 45 (06). 39 (2019)

9. Y. Zhang, Q. Qiao, Y. Yao, L. Fang, J. Guo, W.N. Bai. J. CPRE. 25 (06). 12 (2015)

10. X.M. Sun, Z.J. Cui, L. Zhu, L. Liu. J. CPRE. 20 (01). 124 (2010)

11. N.Z. Xu, W.H. Zeng, P.L. Xue, F. Dong, G.M. Zhou. J. CPRE. 20 (03). 44 (2010)

12. Q. Qiao. J. JEET. 1 (01). 82 (2011)

13. B.J. Lai, J.P. Tian, W. Liu, T. Liu, L.J. Chen. J. AES. 34 (22). 6745 (2014) 